\section{DETAILED METHODS}

Plasmids. The cDNA for HP1 $\alpha$ was described previously $^{1}$ and a kind gift from Benjamin Garcia, while the cDNA for MPP8 was amplified by reverse transcription and PCR on total RNA extracted from MCF7 cells. The chromodomains of MPP8 and HP1 $\alpha$ were inserted in pGEX-6P-1 using BamHI and XhoI (NEB) to generate pGEX-MPP $8_{\text {СнRОмо }}$ and pGEX-HP $1 \alpha_{\text {СнRОмо }}$ plasmids.

The following primers were used:

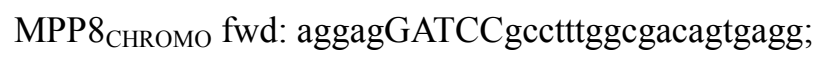
MPP8 ${ }_{\text {СнRомо }}$ rev: gaatCtcGAGctAcctgactgctttggetttgttc;

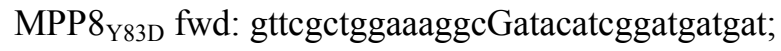
MPP8Y83D rev: atcatcatccgatgtatCgcctttccagcgaac; MPP $8_{\text {Y83F }}$ fwd: gttcgctggaaaggctTtacatcggatgatgat; MPP8 $_{\text {Y83F rev: atcatcatccgatgtaAagcctttccagcgaac; }}$ HP1 $\alpha_{\mathrm{Y} 20 \mathrm{D}}$ fwd: gaggatgaggaggagGatgttgtggagaaggtg; HP $1 \alpha_{\mathrm{Y} 20 \mathrm{D}}$ rev: caccttctccacaacatCctcctcctcatcctc; HP $1 \alpha_{\mathrm{Y} 20 \mathrm{~F}}$ fwd: gaggatgaggaggagtTtgttgtggagaaggtg; HP $1 \alpha_{\mathrm{Y} 20 \mathrm{~F}}$ rev: caccttctccacaacaAactcctcctcatcctc.

The point mutations in HP1 $\alpha$ and MPP8 were introduced by PCR using the primers above, Turbo Pfu (Stratagene), followed by DpnI (NEB) digestion. All constructions were verified by Sanger sequencing (Beckman Coulter Genomics).

Antibodies. HRP-conjugated $\alpha$-GST (ab3416) and $\alpha-\mathrm{H} 3$ (ab1791) were obtained from Abcam, while $\alpha$-FLAG M2 agarose (A2220) $\alpha$-HA-7 agarose (A2095), and HRP-conjugated $\alpha$-FLAG M2 (A8592) were purchased from Sigma.

Cell culture and transfections. Human embryonic kidney HEK293T cells were maintained at $37^{\circ} \mathrm{C}$ with $5 \%$ $\mathrm{CO}_{2}$ in DMEM (Invitrogen) supplemented with $10 \%$ FBS. Cells were seeded at 3E06 per $100 \mathrm{~mm}$ dish and transfected the following day with $18 \mu \mathrm{g}$ plasmid DNA using $54 \mu \mathrm{L}$ TransIT LT1 as recommended by manufacturer (Mirus).

Isolation of nucleosomes from human cells. Approximately 1E08 HEK293T cells (25 150mm petri dishes) were harvested by scraping with ice cold phosphate buffered saline (PBS supplemented with EDTA-free protease inhibitor cocktail from Roche), collected by centrifugation, and resuspended in 2.5 cell pellet volumes (about $4 \mathrm{~mL}$ ) of hypotonic buffer (HB: 10mM HEPES $\mathrm{pH} 7.9,10 \mathrm{mM} \mathrm{KCl}, 1.5 \mathrm{mM} \mathrm{MgCl}_{2}, 340 \mathrm{mM}$ sucrose, $10 \%$ glycerol, $50 \mu \mathrm{g} / \mathrm{mL}$ BSA, $5 \mathrm{mM} \beta$-mercaptoethanol, and EDTA-free protease inhibitor cocktail [Roche]). When cells were resuspended, an equal volume of $\mathrm{HB}$ $(0.2 \%$ triton $\mathrm{X}-100)$ was added and cells incubated for 10 more minutes on ice with occasional gentle inversion, then centrifuged 5 minutes at $1300 \mathrm{~g}$ to isolate nuclei. The nuclei pellet was then gently resuspended in 6 pellet volumes of HB. This nuclei suspension was then applied on a $10 \mathrm{~mL}$ sucrose cushion (10mM HEPES $\mathrm{pH} 7.9,30 \%$ sucrose, $1.5 \mathrm{mM} \mathrm{MgCl}_{2}$, EDTA-free protease inhibitor cocktail [Roche]) and centrifugated at $4^{\circ} \mathrm{C}$ and $1300 \mathrm{~g}$ for 12 minutes. The cleaned nuclei pellet was resuspended in 2 pellet volumes of HB, nucleic acid content measured $(2 \mu \mathrm{L}$ suspension diluted in $100 \mu \mathrm{L} 2 \mathrm{M} \mathrm{NaCl}$, briefly sonicated, and $\mathrm{OD}_{260 \mathrm{~nm}}$ measured on a Nanodrop). The nuclei suspension was then diluted to 1.2$1.6 \mu \mathrm{g} / \mu \mathrm{L}$ DNA concentration and supplemented with $\mathrm{CaCl}_{2}$ to a final concentration of $1 \mathrm{mM}$. The nucleosomes were released by micrococcal nuclease digestion for 5-10 minutes $37^{\circ} \mathrm{C}$ using 1-1.5 units of MNase (Worthington; LS004798) per 100 $\mu$ g of DNA. The digestion was stopped using EDTA at a final concentration of $5 \mathrm{mM}$. The cellular debris were discarded by a 5 minutes centrifugation at $4^{\circ} \mathrm{C}$ and nucleosome-containing supernatant stored at $-20^{\circ} \mathrm{C}$.

Recombinant protein expression and purification. pGEX-MPP $8_{\text {CHROMO }}$ and pGEX-HP $1 \alpha_{\text {CHROMO }}$ plasmids were transformed into BL21-CodonPlus (DE3)-RIL competent cells (Agilent Technologies). Individual colonies picked and grown in $2 \mathrm{~mL} 2 \mathrm{xYT}(1.6 \%$ tryptone, $1 \%$ yeast extract, $0.5 \% \mathrm{NaCl}$, supplemented with $100 \mu \mathrm{g} / \mathrm{mL}$ penicillin) media overnight in shaker (set at 200$250 \mathrm{rpm}$ ) at $37^{\circ} \mathrm{C}$, scaled up to $250 \mathrm{~mL}$ the following day, grown until optical density $\mathrm{OD}_{600}$ reached 0.5-0.7 (usually 2-3 hours), induced with $0.1 \mathrm{mM}$ IPTG for 2.5 hours, and harvested by centrifugation. Cell pellets were resuspended in $10 \mathrm{~mL}$ lysis buffer $(50 \mathrm{mM}$ Tris- $\mathrm{Cl} \mathrm{pH}$ $7.5,150 \mathrm{mM} \mathrm{NaCl}, 0.05 \% \mathrm{NP}-40$, supplemented with EDTA-free protease inhibitor cocktail [Roche] and lysozyme [Thermo Scientific; 89833]), incubated on ice for half an hour, briefly sonicated, then debris were cleared by centrifugation. The cleared lysates were inverted in the presence of $100 \mu \mathrm{L}$ glutathione-sepharose (GE Healthcare) overnight at $4^{\circ} \mathrm{C}$. The next day, GST-bound sepharose beads were washed 3 times with $10 \mathrm{~mL}$ lysis buffer and once with Tris-Cl $\mathrm{pH} 8.0$ before being eluted with $200-500 \mu \mathrm{L}$ Tris-Cl $\mathrm{pH} 8.0$ containing $10 \mathrm{mM}$ reduced glutathione (Sigma).

Calf thymus histones (CTH) pulldowns. Briefly, $10 \mu \mathrm{g}$ of GST-domain were incubated with $50 \mu \mathrm{g}$ CTH (Worthington) in binding buffer $(50 \mathrm{mM}$ Tris- $\mathrm{HCl} \mathrm{pH}$ $7.5,1 \mathrm{M} \mathrm{NaCl}, 1 \% \mathrm{NP}-40)$. After 1 hour incubation with glutathione-sepharose (GE Healthcare), complexes were washed 3 times with binding buffer, and the bound proteins were subjected to immunoblotting analysis.

Biotinylated histone peptides pulldowns. Biotinylated peptides were acquired from Tebu-Bio (France):

H3 1 -21-biotin (61702);

$\mathrm{H} 3 \mathrm{~K} 4^{\mathrm{mel}}$-biotin (64355-025);

$\mathrm{H} 3 \mathrm{~K}^{\mathrm{me} 2}$-biotin (64356-025);

$\mathrm{H} 3 \mathrm{~K}^{\mathrm{me}}{ }^{3}$-biotin (64357-025);

H3K9 ${ }^{\text {mel }}$-biotin (64358-025);

H3K9 ${ }^{\text {me2 }}$-biotin (64359-025);

H3K9 ${ }^{\text {me3 }}$-biotin (64360-025). 
Essentially, $2 \mu \mathrm{L}$ of GST or indicated GST-MPP8 were incubated with $1 \mu \mathrm{g}$ of biotinylated histone $\mathrm{H} 3$ peptides in $500 \mu \mathrm{L}$ binding buffer $(50 \mathrm{mM}$ Tris- $\mathrm{Cl} \mathrm{pH} 7.5,200 \mathrm{mM}$ $\mathrm{NaCl}, 0.05 \% \mathrm{NP} 40$ ) and incubated overnight at $4{ }^{\circ} \mathrm{C}$ with inversion. The next day, $25 \mu \mathrm{L}$ of 50:50 streptavidinsepharose (GE Healthcare) suspension were added and samples incubated for an additional hour before washing the beads 4 times with $1 \mathrm{~mL}$ binding buffer. Beads were finally resuspended in $20 \mu \mathrm{L}$ Laemmli sample buffer and $5 \mu \mathrm{L}$ were loaded for analysis by SDS-PAGE. For the input, $2 \mu \mathrm{L}$ of GST proteins were diluted in $20 \mu \mathrm{L}$ Laemmli sample buffer and $5 \mu \mathrm{L}$ loaded (25\% input).

Chromatin immunoprecipitations (ChIP). Essentially, 3E06 HEK293T cells were seeded on 100mm plates and transfected the next day. Cells were collected in PBS 48 hours post-transfection, resuspended in $600 \mu \mathrm{L}$ of IPH150 buffer $(50 \mathrm{mM}$ Tris- $\mathrm{HCl} \mathrm{pH} 8.0,150 \mathrm{mM} \mathrm{NaCl}, 0.5 \%$ NP40), briefly sonicated, and incubated with $1 \mathrm{mM}$ $\mathrm{CaCl}_{2}$ and 120 units micrococcal nuclease (Worthington
LS004798) at room temperature for 30 minutes with occasional gentle mixing. The cell lysates were cleared by centrifugation, added to $40 \mu \mathrm{L}$ 50:50 $\alpha \square$ FLAG $\square \mathrm{M} 2$ agarose (Sigma) slurry, and inverted overnight at $4^{\circ} \mathrm{C}$. The beads were washed four times with IPH-750 buffer (50mM Tris- $\mathrm{HCl} \mathrm{pH} 8.0,750 \mathrm{mM} \mathrm{NaCl}, 0.5 \% \mathrm{NP} 40$ ), beads $\square$ bound proteins were resolved by SDS-PAGE, transferred to nitrocellulose membranes, and analysed by immunoblotting with indicated antibodies.

\section{REFERENCES}

1. Binda, O.; LeRoy, G.; Bua, D. J.; Garcia, B. A.; Gozani, O.; Richard, S., Trimethylation of histone H3 lysine 4 impairs methylation of histone $\mathrm{H} 3$ lysine 9: regulation of lysine methyltransferases by physical interaction with their substrates. Epigenetics : official journal of the DNA Methylation Society 2010, 5 (8), 767-775. 